$\triangle N$ N A L E S

UNIVERSITATIS MARIAE CURIE-SKLODOWSKA L U B L I N - P O L O N I A

VOL. XXVIII, 5

SECTIO A 1974

Instytut kkonomll Polityczne」 1 Plunowunla, Uniworgytut Maril Curle-skiodowrkiej. Lublin Department of Mathomatica, State Univorgity of New York, Brockport, Now York 11420, Usi Instytut Matcmatyki, Uniwersytet Maril Curie-Sklodow'sklej, Lublin

ZDZISEAW LEWANDOWSKI, SANFORD NIII,ER I, FIJGIUSZ ZŁOTKIEW ICZ

\title{
Gamma-Starlike Functions
}

Funkcje gama-gwieździste

Гамма-звездообразные функции

1. In recent papers $[3,4,5]$ several authors have investigated regular function $f(z)$, defined in the unit disc $D$, with the property that the real part of an arithmetic mean of the quantities $\left(z f^{\prime}(z) / f(z)\right)$ and $\left(1+z f^{\prime \prime}(z) / f^{\prime}(z)\right)$ is positive, i.e.

$$
\operatorname{Re}\left[(1-\alpha) z \frac{f^{\prime}(z)}{f(z)}+\alpha\left(1+z \frac{f^{\prime \prime}(z)}{f^{\prime}(z)}\right)\right]>0
$$

for $z \in D$ and for some fixed real $a$. Functions satisfying this condition are said to belong to the class of alpha-convex (or alpha-starlike) function. $\mathscr{M}_{a}$, and they have been shown to be starlike. In this paper we consider regular functions $f(z)$, defined in $D$, with the property that the real part of a geometric mean of the quantities $z f^{\prime}(z) / f(z)$ and $1+z f^{\prime \prime}(z) / f^{\prime}(z)$ is positive. We will show that these functions are starlike and will call such functions gamma-starlike to suggest the use of the geometric mean in their definition.

Definition 1. Let $f(z)=z+\sum_{a}^{\infty} a_{n} z^{n}$ be regulas in the unit dise $D$, with $f(z), f^{\prime}(z)$ and $\left[1 ; z f^{\prime \prime}(z) / f^{\prime}(z)\right] \neq 0$ in $0<|z|<1$. Suppose $\gamma$ is real and

$$
\operatorname{Re}\left[\left(\frac{z f^{\prime}(z)}{f(z)}\right)^{1-\gamma}\left(1+\frac{z f^{\prime \prime}(z)}{f^{\prime}(z)}\right)^{\gamma}\right]>0
$$

for $z \in D$, where the powers appearing in (1) are meant as principal values.

1 This work was carried out while the second author was an IREX Scholar in Poland. 
Then we say that $f(z)$ is a gamma-starlike function and we denote the class of such functions by $\mathscr{L}^{\prime}$.

Remarks. (i) Condition (1) is equivalent to the following condition:

$$
\left|(1-\gamma) \arg \frac{z f^{\prime}(z)}{f(z)}+\gamma \arg \left(1+\frac{f^{\prime \prime}(z)}{f^{\prime}(z)}\right)\right|<\frac{\pi}{2}
$$

(ii) If $\gamma=0, \mathscr{L}_{0} \equiv S^{*}$, the class of starlike functions, while if $\gamma=1$, $\mathscr{L}_{1} \equiv C$, the class of convex functions.

2. We now show that if $f(z)$ is a gamma-starlike function then $f(z)$ is starlike and univalent.

Theorem 1. $\mathscr{L}_{\gamma} \subset S^{*}$, for all real $\gamma$.

Proof. If $f(z) \in \mathscr{L}_{\gamma}$ and we set

$$
\frac{1+w(z)}{1-w(z)}=\frac{z f^{\prime}(z)}{f(z)}
$$

for $z \in D$, then $w(0)=0, w(z) \neq \pm 1$ and $w(z)$ is a meromorphic function. We will show that $|w(z)|<1$, and this will imply that

$$
\operatorname{Re}\left[z f^{\prime}(z) / f(z)\right]>0 .
$$

Iet $w(z)=R(z) e^{i \varphi(z)}, R \geqslant 0$ for $z \in D$, and suppose that $z_{0}$ is a point of $D$ such that

$$
\max _{|z|<\left|z_{0}\right|}|w(z)|=\left|w\left(z_{0}\right)\right|=1
$$

Then $\frac{\partial}{\partial^{\theta}} R\left(z_{0}\right)=0$, and since

$$
\frac{z w^{\prime}(z)}{w(z)}=\frac{\partial \Phi(z)}{\partial \theta}-i \frac{1}{R} \frac{\partial R(z)}{\partial \theta},
$$

we must have $z_{0} w^{\prime}\left(z_{0}\right) / w\left(z_{0}\right)=\partial \Phi\left(z_{0}\right) / \partial \theta$, and hence $z_{0} w^{\prime}\left(z_{0}\right) / w\left(z_{0}\right)$ must be a real number. A simple geometric argument can show even more. If we assume $\partial \Phi\left(z_{0}\right) / \partial \theta<0$ then $v(z)$ would be locally univalent at $z_{0}$ and this would lead to a contradiction of (4). Thus we see that $\partial \Phi\left(z_{0}\right) / \partial \theta$ must be non-negative and so we can set

$$
\frac{z_{0} w^{\prime}\left(z_{0}\right)}{w\left(z_{0}\right)}=B,
$$

where $B \geqslant 0$. 
Since $\left|w\left(z_{0}\right)\right|=1$ and $w\left(z_{0}\right) \neq \pm 1$, we must have

$$
\frac{1+w\left(z_{0}\right)}{1-w\left(z_{0}\right)}=\boldsymbol{A} i,
$$

where $A$ is real and $A \neq 0$.

From (1) and (3) we have

$\operatorname{Re} I(\gamma, f(z))=$

$$
=\operatorname{Re}\left[\left(\frac{1+w(z)}{1-w(z)}\right)^{1-\gamma}\left(\frac{1+w(z)}{1-w(z)}+\frac{z w^{\prime}(z)}{w(z)}\left(\frac{w(z)}{1+w(z)}+\frac{w(z)}{1-w(z)}\right)\right)^{\prime}\right]
$$

where

$$
I(\gamma, f(z)) \equiv\left(\frac{z f^{\prime}(z)}{f(z)}\right)^{1-\gamma}\left(1+z \frac{f^{\prime \prime}(z)}{f^{\prime}(z)}\right)^{\gamma}
$$

and thus at $z=z_{0}$, by using (5) and (6) we obtain

$$
\operatorname{Re} I\left(\gamma, f\left(z_{0}\right)\right)=\operatorname{Re}\left[(A i)^{1-\gamma}\left(A i+\frac{B}{a}\left(A+\frac{1}{A}\right) i\right]^{\gamma} .\right.
$$

If we let $C=A+B(A+1 / A) / 2$, then since $B \geqslant 0$ and $A \neq 0$ we have $A C>0$ and obtain

$$
\operatorname{Re} I\left(\gamma, f\left(z_{0}\right)\right)=\operatorname{Re}\left[(A i)^{1-\gamma}(C i)^{\gamma}\right]=\operatorname{Re}\left(|A|^{1-\gamma}|C|^{\gamma} i\right)=\mathbf{0} .
$$

This is a contradiction of (1) and so we must have $|w(z)|<1$ for $z \epsilon D$ and thus $f(z) \in \mathbb{S}^{*}$.

Note that Theorem 1 shows that if $f_{\epsilon} \mathscr{L}_{\gamma}$, then $f \epsilon \mathscr{L}_{0} \equiv S^{*}$. We can show more than this.

Theorem 2. If $0 \leqslant \delta \leqslant \gamma$ (or $\gamma \leqslant \delta \leqslant 0$ ) then $\mathscr{L}_{\gamma} \subset \mathscr{L}_{\sigma}$.

Proof. The case $\delta=0$ has been handled in Theorem 1 , so we only need to consider the case $0<\delta / \gamma<1$.

If $f \in \mathscr{L}_{\gamma}$, then there is a function $P_{1}(z) \in \mathscr{P} \equiv\{P(z) \mid P(0)=1, P(z)$ is regular in $D$ and $\operatorname{Re} P(z)>0$ \} satisfying

$$
\left(\frac{\left(z f^{\prime}(z)\right.}{f(z)}\right)^{1-\gamma}\left(1+\frac{z f^{\prime \prime}(z)}{f^{\prime}(z)}\right)^{\gamma} \equiv P_{1}(z) .
$$

By Theorem 1 we have $f(z) \in S^{*}$ and hence there exists $P_{2}(z) \in \mathscr{P}$ such that

$$
\frac{z f^{\prime}(z)}{f(z)} \equiv P_{2}(z)
$$


If we raise sides of $(7)$ to the $\delta / \gamma$ power we obtain

$$
\left(\frac{\left(z f^{\prime}(z)\right.}{f(z)}\right)^{\delta / \gamma^{-\delta}}\left(1+\frac{z f^{\prime \prime}(z)}{f^{\prime}(z)}\right)^{\delta} \equiv P_{1}(z)^{\delta / \gamma},
$$

and if we raise both sides of $(8)$ to the $(1-\delta / \gamma)$ power we obtain

$$
\left(\frac{z f^{\prime}(z)}{f(z)}\right)^{1-\delta / \gamma}=P_{2}(z)^{1-\delta / \gamma} .
$$

Multiplying equation (9) by equation (10) we obtain

$$
\left(\frac{z f^{\prime}(z)}{f(z)}\right)^{1-\delta}\left(1+\frac{z f^{\prime \prime}(z)}{f^{\prime}(z)}\right)^{s} \equiv P_{1}(z)^{\delta / \gamma} P_{2}(z)^{1-\delta / \gamma} \equiv P_{3}(z)
$$

Since $P_{1}(z) \in \mathscr{P}$ and $P_{2}(z) \in \mathscr{P}$, we have $P_{3}(\theta)=1$ and $\left|\arg P_{3}(z)\right| \leqslant \frac{\delta}{\gamma}$ $\left|\arg P_{1}(z)\right|+\left(1-\frac{\delta}{\gamma}\right)\left|\arg P_{2}(z)\right|<\pi / 2$, i.e. Re $P_{3}(z)>0$ and $P_{3}(z)+\mathscr{P}$, Consequently from (10) we have $f(z) \in \mathscr{L}_{\gamma}$.

Note that the last theorem shows that if $f(z) \in \mathscr{L}$ and $\gamma^{\prime} \geqslant 1$, then $f(z)$ is a convex function.

3. It is possible to obtain bounds on the coefficients of gamma-starlike functions by using certain "standard" methods.

Theorem 3. If $f \in \mathscr{L}_{\gamma}, f(z)=z+a_{2} z^{2}+n$, and if $\mu$ is a complex constant, then

(14) $(1+\gamma)^{2}|1+2 \gamma|\left|a_{3}-\mu a_{2}\right| \leqslant \operatorname{Max}\left[(1+\gamma)^{2},|4 \mu(1+2 \gamma)-3(3 \gamma+1)|\right]$ all hold.

Remarks. (i) $\gamma=0$ (14) reduces to

$$
\left|a_{3}-\mu a_{2}^{2}\right| \leqslant \operatorname{Max}[1,|4 \mu-3|],
$$

which is a result of Keogh and Merkes [2].

(ii) For $\gamma=1$ (14) reduces to

$$
\left|a_{3}-\mu a_{2}^{2}\right| \leqslant \operatorname{Max} .\left[\frac{1}{3},|\mu-1|\right] .
$$

(iii) If $f(z) \in \mathscr{L}_{\gamma}, \gamma \geqslant 0$, then

$$
\left|a_{2}\right| \leqslant 2 /(1+\gamma)
$$


and

$$
\left|a_{3}\right| \leqslant\left\{\begin{array}{l}
\frac{3(3 \gamma+1)}{(1+2 \gamma)(1+\gamma)^{2}}, 0 \leqslant \gamma \leqslant \frac{7+\sqrt{57}}{2} \\
\frac{1}{1+2 \gamma}, \frac{7+\sqrt{57}}{2}<\gamma .
\end{array}\right.
$$

hold.

Inequalities (12) - (16) may not be sharj). They would be sharp) if it were possible to prove that the differential equation

$$
\left(\frac{\left(z f^{\prime}(z)\right.}{f(z)}\right)^{1-z^{\prime}}\left(1+z \frac{f^{\prime \prime}(z)}{f^{\prime}(z)}\right)^{\gamma}=\frac{1+z}{1-z},
$$

with initial condition $f(0)=0, f^{\prime}(0)=1$, has a solution that is a regular function in the unit disc. The anthors have not been able to prove this for arbitrary $\gamma$, but suspect that a solution exists for $\gamma \geqslant 0$.

The class $\mathscr{U}_{a}$ satisfies Theorems 1,2 and inequality (13) and it is also true that $\mathscr{H}_{0} \equiv \mathscr{Y}_{0} \equiv S^{*}$ and $\mathscr{H}_{1} \equiv \mathscr{L}_{1} \equiv C$. However, in general $\mathscr{M}_{p}$ $\neq \mathscr{L}_{\beta}$; This can be seen by considering $\beta=1 / 2$. By using infinite series, it is possible to show that (17) does have a regular solution for $\gamma=\beta=1 / 2$, and for this solution $a_{3}=5 / 3$. For functions in $\mathscr{M}_{1 / 2}$ we must have $\left|a_{3}\right| \leqslant 29 / 18[3]$, and thus $\mathscr{H}_{1 / 2} \neq \mathscr{L}_{1 / 2}$.

We conclude by indicating a refinement in the class of gamma-starlike functions.

Definition 2. Let $f(z)=z+\sum_{2}^{\infty} a_{n} z^{n}$ be regular in the unit disc $D$ with $f(z), f^{\prime}(z), 1+z f^{\prime \prime}(z) / f^{\prime}(z) \neq 0$ in $0<|z|<1$, and suppose $\gamma$ is a real constant, $0 \leqslant \gamma<1$. If

$$
\operatorname{Re}\left[\left(\frac{z f^{\prime}(z)}{f(z)}\right)^{1-\gamma}\left(\left(1+z \frac{f^{\prime \prime}(z)}{f^{\prime}(z)}\right)^{\gamma}\right]>a .\right.
$$

for $z \in D$, then we say that $f(z)$ is a gamma-starlike function of order $\alpha$, and we denote the class of such functions by $\mathscr{L}_{\gamma}(\alpha)$. If $(18)$ is replaced by

$$
\left|(1-\gamma) \arg \left(\frac{z f(z)}{f(z)}\right)+\gamma \arg \left(1+\frac{z f^{\prime \prime}(z)}{f^{\prime}(z)}\right)\right|<\frac{\pi}{2} a
$$

for $z \in D$, then we say that $f(z)$ is a strongly gamma-starlike function of order $\alpha$, and we denote the class of such functions by $\mathscr{L}_{\gamma}^{*}(\alpha)$.

Note that $\mathscr{L}^{*}(\alpha)$ and $\mathscr{L}_{1}^{*}(\alpha)$ are respectively the classes of strongly-starlike and strongly-convex functions of order $a$ introduced by Brannan and Kirwan [1]. 


\section{REF'ERENES}

[1] Brannan D. A. and Kirwan W. E., On Some Classes of Bounded Univalent Functions, London Math. (2). I (1969), $437-443$.

[2] Keogh F. R. and Merkes E. P., A Coefficient Inequality for Certain Olasses of Analytic Functions, Proc. Amer. Math. Soo. 20 No 1, (1969) 8-12.

[3] Kulshrestha P. K., Coefficients for Alpha-Oonvex Functions, Bull. Amer. Math. Soc. (to appear).

[4] Miller S. S., Distortion Properties of Alphr-Starlike Functions, Proc. Amer. Math. Soc., 38 (1973), $311-318$.

[5] Miller S.S., Mocanu P. and Reade M. O., All Alpha-Convex Functions are Univalent and Starlike, Proc. Amer. Math. Soc., 37 (1973), 553 - 554.

[6] Stankiewicz J., Some Remarks Concerning Starlike Functions Bull. Pol. Acad. Sci. 18(1970), 143-146.

\section{STRESZCZENIE}

Niech $f(z)=z+\sum_{2}^{\infty} a_{n} z^{n}$ będzie funkcją holomorficzną $w$ kole jednostkowym $D=\{z:|z|<1\}$ i taką, że $f(z) \neq 0, f^{\prime}(z) \neq 0$ oraz

$$
1+z f^{\prime \prime}(z) / f^{\prime}(z) \neq 0 \quad \text { dla } \quad 0<|z|<1 .
$$

Jeśli zachodzi nierówność

$$
\operatorname{Re}\left\{\left[z f^{\prime}(z) / f(z)\right]^{1-\gamma}\left[z f^{\prime \prime}(z) / f^{\prime}(z) ;-1\right]\right\}>0 \text { dla } z \in D
$$

dla dowolnego, ustalonego rzeczywistego $\gamma$ to mówimy, że $f(z)$ jest funkcją gamma. -gwiaździsta.

W pracy tej autorzy dowodzą, że funkcje gamma-gwiaździste są jednolistne i gwiaź. dziste. Podane są też pewne oszacowania współczynników dla rozważanych funkcji-

\section{P Е 3 Ю $\mathrm{E}$}

Пусть $f(z)=z+\sum_{2}^{\infty} a_{n} z^{n}$ будет голоморфной функцией в едвничном круте $D=\{z:|z|<1\}$ подчиненной условиям $f(z) \neq 0, f^{\prime}(z) \neq 0$ и $1+z f^{\prime \prime}(z) \mid f^{\prime}(z) \neq 0$ для $0<|z|<1$.

Если исполнится неравенство для вещественого фиксированного $\gamma$

$$
\operatorname{Re}\left\{\left[z f^{\prime}(z) / f(z)\right]^{1-\gamma}\left[z f^{\prime \prime}(z) / f^{\prime}(z)+1\right]\right)<0 \text { для } z \in D
$$

то тогда мы говорим, что $f(z)$ - это гамма-звездообразная функция.

Авторы доказывают, что гамма-звездообразные являются однолистными и звездообразными функциямя. Даются также некоторые оценки козффициентов рассматрнваемых функция̆. 